\title{
Protein Changes in Peach Seeds during Chilling Are Not Associated with Breaking Dormancy
}

\author{
Ahmed Mahhou' and Frank G. Dennis, Jr. \\ Department of Horticulture, Michigan State University, East Lansing, MI 48824-1325 \\ Additional index words. embryo, gibberellic acid, imbibition, Prunus persica, stratification, temperature, water content
}

\begin{abstract}
Siberian C peach (Prunus persica L.) seeds were stratified at 5 and 20C. DWs and soluble protein content remained constant regardless of stratification temperature and duration. Seed extracts subjected to sodium dodecyl sulfate-polyacrylamide gel electrophoresis revealed a decrease in the intensity of nine polypeptides in the cotyledons of seeds held at 5C during weeks 5 through 8 , coinciding with an increase in germination capacity. These changes were confined to cotyledons held at $5 \mathrm{C}$, and were observed only when the seeds were able to germinate. The effects of stratification and the imbibition degree on changes in the protein content of seeds of two additional peach biotypes ('Farouki' and 'Maloussi') were also evaluated. Germination of fully imbibed seeds at 20C increased steadily as stratification time at $5 \mathrm{C}$ increased. Partially imbibed seeds (25\% or 50\% of full imbibition) did not germinate regardless of stratification time. However, when these seeds were soaked in water after stratification, their germination paralleled that of fully imbibed seeds. Thus, dormancy was broken, even though the seeds could not germinate. Changes in protein profiles in fully imbibed seeds confirmed those previously reported for Siberian $\mathrm{C}$ seeds. Similar changes occurred in cotyledons of partially imbibed seeds during stratification at $5 \mathrm{C}$, but at a slower rate. Those changes were, however, delayed by partial imbibition, whereas germination capacity (ability to germinate when fully imbibed) was not. Changes in cotyledon protein profiles were not affected by removing the embryonic axis before stratification, a result indicating that such changes are not controlled by the axis. Gibberellic acid $\left(\mathrm{GA}_{3}\right.$ induced $35 \%$ to $40 \%$ germination of nonchilled seeds. It hastened the loss of protein band intensity in 'Farouki' but not in 'Maloussi'. However, GA $\mathbf{A}_{3}$-treated seeds germinated before any visible changes occurred in protein profiles. We conclude that the effects of chilling on breaking dormancy are independent of its effects on the protein changes observed in this study.
\end{abstract}

Dormant seeds of many species, such as peach, must be exposed to low temperatures (stratified) before they can germinate. Much effort has been devoted to understanding the action of low temperatures in breaking dormancy. Several studies have emphasized protein changes associated with chilling.

When Heracleum sphondylium L. seeds were held moist at 2C, reserve proteins were hydrolyzed in the endosperm and transferred to the embryo; this did not occur in seeds kept at 15C (Stokes, 1952). In apple (Malus domestica Borkh.) embryos, however, reserve protein hydrolysis occurred at 5 and 20C (Bouvier-Durand et al., 1983). Further, proteolysis was absent in seeds held in the fruit at $0 \mathrm{C}$, although this treatment broke embryo dormancy.

Changes in total soluble protein content during chilling were insignificant in pear (Pyrus communis L.) embryos (Alscher-Herman and Khan, 1980) and in apple axes and cotyledons (Eichholtz et al., 1983). Although the concentrations of four polypeptides increased in the axes of apple seeds held at $5 \mathrm{C}$, no changes were apparent at 20C or in cotyledons held at either temperature (Eichholtz et al., 1983). These authors suggested that protein reserves may be mobilized to the axes when dormancy is broken.

In sugar pine (Pinus lambertiana Dougl.), four protein bands were consistently more intense in extracts of embryos from seeds held at $25 \mathrm{C}$ than in those held at $5 \mathrm{C}$, although dormancy was broken only at 5C (Noland and Murphy, 1986). These authors speculated that such proteins may inhibit germination in dormant seeds.

Callaway (1988) followed protein changes in peach buds and seeds during chilling. Response varied with protein band, some increasing in intensity with chilling and some decreasing relative to controls held at $25 \mathrm{C}$. Radiolabeling with ${ }^{35} \mathrm{~S}$-methionine gave

Received for publication 18 May 1992. Accepted for publication 21 May 1993. The cost of publishing this paper was defrayed in part by the payment of page charges. Under postal regulations, this paper therefore must be hereby marked advertisement solely to indicate this fact.

Present address: Dept. of Horticulture, Institut Agronomique et Veterinaire Hassan II, Rabat, Morocco. similar results. Callaway suggested that proteins that accumulated at $25 \mathrm{C}$ inhibited, while those that accumulated at $4 \mathrm{C}$ stimulated, breaking dormancy.

Lang and Tao (1991), working with peach flower buds, observed a substantial decrease in a $61-\mathrm{kDa}$ protein during the final stages of chilling. Its role in dormancy has yet to be determined.

The objective of our study was to assess the relationship between protein changes and breaking dormancy in peach seeds.

\section{Materials and Methods}

Plant material. Siberian C peach pits were obtained from Hilltop Nurseries, Hartford, Mich., and 'Farouki' and 'Maloussi' (local Moroccan seedlings used as rootstock) were purchased from seed collectors in the Missour region of Morocco. All seeds were from open-pollinated flowers. After pencarp removal, the pits were washed, dried at 20C, and stored at 5C until used.

Stratification, germination, and fresh and dry weights (DWs). Seeds were removed from the pits with a mechanical cracker and soaked in $N$-(trichloromethyl) thio-4-cyclohexene-1,2-dicarboximide (captan) solution $(0.03 \%)$ for $72 \mathrm{~h}$. The seeds were stratified on sterile filter paper moistened with captan in Petri dishes held in darkness at either $5 \mathrm{C}$ or $20 \mathrm{C}$ for 1 to 10 weeks. To evaluate germination capacity, three replications of 10 seeds each were held in Petri dishes at 20C in darkness. The seeds were considered to have germinated when the radicle had elongated $3 \mathrm{~mm}$ or more after 14 days. Thirty seeds from each treatment were dissected into cotyledons and embryonic axes to determine fresh and dry weights. Fresh weights were recorded immediately after dissection and DWs after $72 \mathrm{~h}$ at $90 \mathrm{C}$.

Protein content analysis. To determine soluble protein content, 10 embryonic axes were extracted in $0.5 \mathrm{ml}$ of $62.5 \mathrm{~mm}$ tris- $\mathrm{HCl}$ $(\mathrm{pH} 6.8)$ in a small mortar. The homogenate, along with two 0.25$\mathrm{ml}$ rinses, was left overnight at room temperature $(\approx 20 \mathrm{C})$ and cleared by centrifugation at $23,00 \times g$ for $20 \mathrm{~min}$. The supernatant 
was filtered through Whatman no. 1 filter paper and stored in a freezer. One cotyledon was removed from each of eight seeds. The eight cotyledons were homogenized in $2 \mathrm{ml}$ of the same buffer in a small mortar. The homogenate, with two 1-ml rinses, was treated as above.

Protein content was determined according to Bradford's (1976) method. This assay is based on the shift in absorbance for an acidic solution of Coomassie Brilliant Blue G-250 from $465 \mathrm{~nm}$ to 595 $\mathrm{nm}$ when protein binding occurs.

For sodium dodecyl sulfate-polyacrylamide gel electrophoresis (SDS-PAGE), samples were extracted as described above with $62.5 \mathrm{~mm}$ tris- $\mathrm{HCl}$ containing SDS (2\%), glycerol (10\%), 2-ßmercaptoethanol $(5 \%)$, and bromophenol blue $(0.002 \%$, as a tracking dye). Electrophoresis was performed according to Laemmli (1970), with $12 \%$ (w/v) polyacrylamide on $1.5-\mathrm{mm}$ slab gels for separating and $4 \%(\mathrm{w} / \mathrm{v})$ for stacking gels at constant temperature (20C) and constant current of $20 \mathrm{~mA}$. Fifty $\mu \mathrm{g}$ of protein was loaded per well. Gels were stained with Coomassie Brilliant Blue R-250 in $40 \%$ methanol plus $10 \%$ glacial acetic acid for $4 \mathrm{~h}$, then destained for $12 \mathrm{~h}$. Three replicate gels were run for each sampling date.

The relative nobilities and molecular weights (MWs) of the proteins were determined by comparing them with those of proteins of known MWs. Low-range MW standards (Bio-Rad, Richmond, Calif.) were used in each electrophoretic run. The six standards and their MWs (in kiloDaltons) were rabbit muscle phosphorylase b, 97.4; bovine serum albumin, 66.20; hen egg white ovalbumin, 42.699; bovine carbonic anhydrase, 31.0; soybean trypsin inhibitor, 21 .5; and hen egg white lysozyme, 14.4.

Stratification time and temperature. Siberian C seeds were stratified for 8 weeks at 5C or 20C and samples were removed weekly.

Three remaining experiments were conducted concurrently using one set each of intact, fully imbibed 'Farouki' and 'Maloussi' seeds as controls. Results are presented only for 'Maloussi', as the two biotypes responded similarly in all but a few instances.

Imbibition degree. The seeds were soaked in distilled water for 5,15 , or $72 \mathrm{~h}$, corresponding to $25 \%, 50 \%$, and $100 \%$ of full imbibition, respectively, as determined by water content. The seeds were wrapped in a piece of cheesecloth, which was attached to the top of a $250-\mathrm{ml}$ jar containing $25 \mathrm{ml}$ of captan solution. The jar was tightly sealed with a cap and Parafilm (American Can Co., Greenwich, Corm.), then held at 5C for 2 to 10 weeks.

Stratification of cotyledons separately from embryonic axis. Seeds that had been imbibed for $72 \mathrm{~h}$ were cut transversely with a razor. The chalazal and micropylar ends of the seeds were stratified independently at $5 \mathrm{C}$. The cotyledons remaining in the chalazal end represented $94 \%$ to $97 \%$ and $89 \%$ to $95 \%$ fresh weight of the intact cotyledons, respectively, for 'Farouki' and 'Maloussi'. After 0 to 8 weeks, the embryonic axis was dissected out. Fresh and dry weights of the cotyledons and the axis were recorded, but germination capacity of the axis was not tested.

Gibberellic acid. $\mathrm{GA}_{3}$ stimulates germination in partially chilled peach seeds (Donoho and Walker, 1957). To determine if protein hydrolysis was also hastened by $\mathrm{GA}_{3}$, 'Farouki' and 'Maloussi' seeds were soaked in distilled water for $48 \mathrm{~h}$, then some of the seeds were transferred to a $\mathrm{GA}_{3}$ solution $(500 \mathrm{ppm})$ for the remaining 24 $\mathrm{h}$ of a 72-h imbibition period. Control seeds were held for $72 \mathrm{~h}$ in water.

For each treatment, the following data were recorded at 2-week intervals: fresh and dry weights; germination at 20C with and without additional imbibition (three replications of 10 seeds each per treatment); and soluble protein content and protein profiles for axes and cotyledons.

\section{Results}

Stratification time and temperature. Siberian $\mathrm{C}$ seeds held at $20 \mathrm{C}$ did not germinate. Those held at $5 \mathrm{C}$ began to germinate after 5 weeks, and germination percentage increased with time. Germination percentages for weeks 5 through 8 were $20 \%, 45 \%, 75 \%$, and $94 \%$, respectively (all significantly different at $P \leq 0.05$ by analysis of variance and Duncan's multiple range test). Fresh weights and water content of cotyledons and embryonic axes increased with time at $5 \mathrm{C}$ and $20 \mathrm{C}$, with a greater rate of increase at $5 \mathrm{C}$ (data not shown). DWs remained constant at $\approx 0.65$ and $260 \mathrm{mg}$, for embryonic axes and cotyledons, respectively. Soluble protein content remained unchanged at $26 \%$ to $28 \%$ DW (cotyledons) and $14 \%$ to $16 \%$ (embryonic axes), regardless of temperature or stratification time (data not shown).

SDS-PAGE revealed a decrease in the concentrations of nine polypeptides (apparent MWs of 66, 54, 48, 47, 41, 39.5, 36, 35, and $33.5 \mathrm{kDa}$ ) in the cotyledons of seeds held at $5 \mathrm{C}$ during weeks 5 through 8 (Fig. 1), coinciding with an increase in germination capacity. These decreases were accompanied by the appearance of several new low-MW (10 to $14 \mathrm{kDa}$ ) polypeptides. None of these changes occurred in the embryonic axes of these seeds (Fig. 1) or in cotyledons or axes of seeds held at 20C.

Imbibition degree. Germination of fully imbibed 'Farouki' and 'Maloussi' seeds at 20C increased steadily as stratification time at $5 \mathrm{C}$ increased (Table 1). Partially imbibed seeds did not germinate regardless of stratification time. However, if these seeds were fully imbibed after stratification, their germination paralleled that of seeds that were fully imbibed before stratification (Table 1). Thus after-ripening occurred even though the seeds could not germinate.

Fresh weight and water content of cotyledons and embryonic axes increased with stratification time of fully imbibed seeds, but the rate of increase was greater at 5 than 20C (data not shown). Data for partially imbibed seeds held at 5C paralleled those of fully imbibed seeds, but all values were lower, as might be expected. Thus, after 8 weeks of stratification, the water content of seed parts of partially imbibed seeds was equal to or less than that of seed parts of fully imbibed but nonstratified seeds. None of the treatments affected axis or cotyledon DWs (data not shown).

Soluble protein content varied from $19 \%$ to $24 \%$ (cotyledons) or $9 \%$ to $12 \%$ (embryonic axes) and was not affected by cultivar, moisture content, or stratification time (data not shown). Changes in protein profiles in fully imbibed seeds of both biotypes, exemplified by 'Maloussi' (Fig. 2), confirmed those previously observed in Siberian C seeds. Decreases in the intensity of nine bands were evident in extracts of the cotyledons after 2 weeks of stratification and the decreases continued until the end of the experiment ( 8 weeks). Again, two low-MW bands appeared at the same time. However, none of these changes occurred in axes of these seeds or in axes or cotyledons of fully imbibed seeds kept continuously at 20C (could not germinate) (Fig. 2). Although the concentrations of polypeptides 5 and 7 (41 and $36 \mathrm{kDa}$, respectively) decreased within 1 week in axes of seeds held at both temperatures, levels of the same polypeptides, or ones of similar MWs, in cotyledons decreased only at 5C. Similar changes occurred in cotyledons of partially imbibed seeds during stratification at $5 \mathrm{C}$, but at a slower rate (Fig. 3). Thus the intensities of bands 5 and 7 in partially imbibed seeds stratified for 10 weeks were about equal to those of the same bands in fully imbibed seeds stratified for only 3 weeks. In 'Farouki' seeds, low-MW bands also were slower to appear, especially in seeds imbibed for only $5 \mathrm{~h}$.

Stratification of cotyledons separately from embryonic axis. Fresh weights and water content of embryonic axes and cotyledons 
$5 \mathrm{C}$

$20 \mathrm{C}$

$012345678 \overline{12345678} \mathrm{~s}$

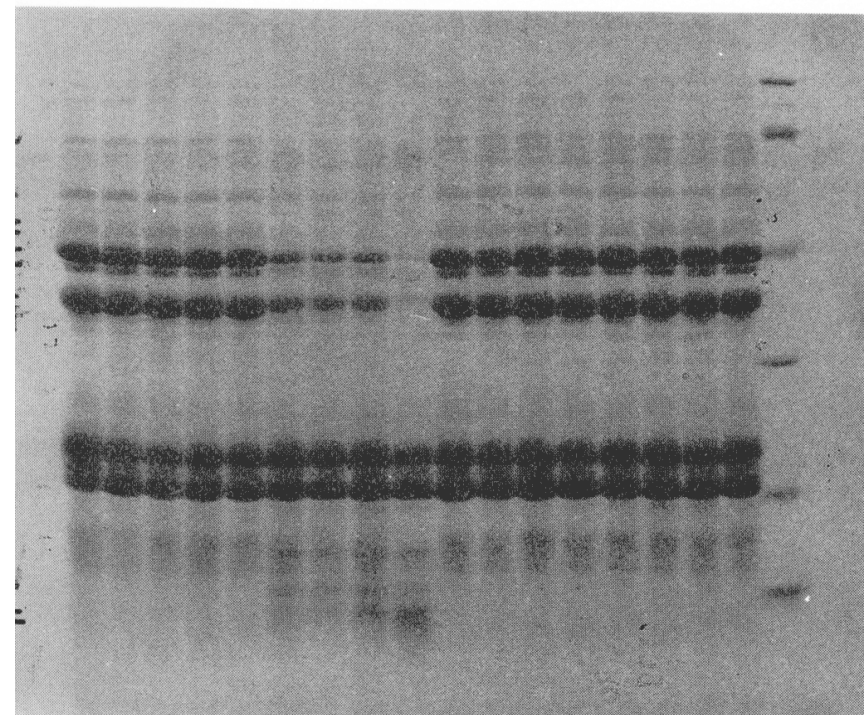

$5 \mathrm{C}$

$20 \mathrm{C}$

012345678 s $\longdiv { 1 2 3 4 5 6 7 8 }$

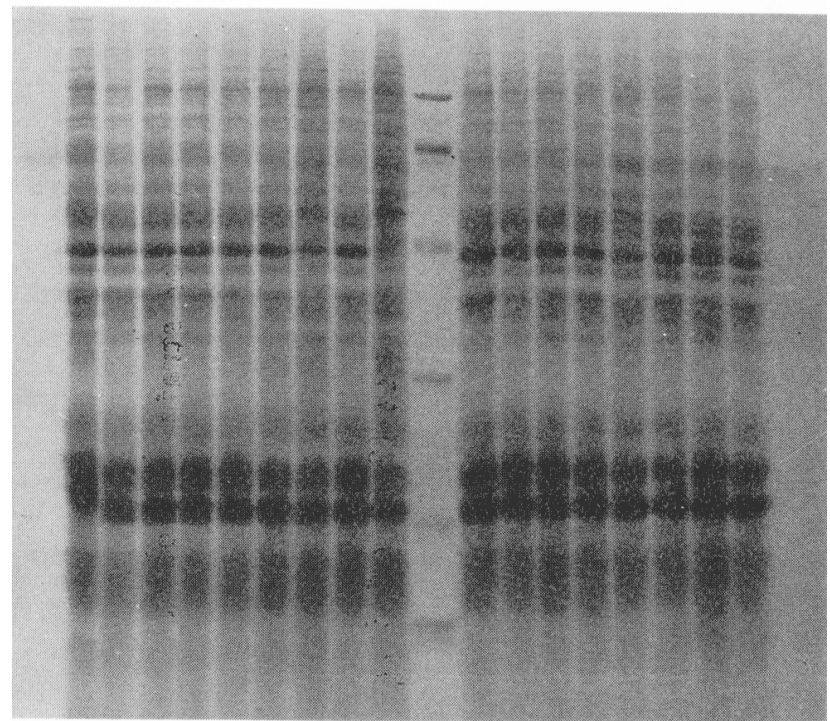

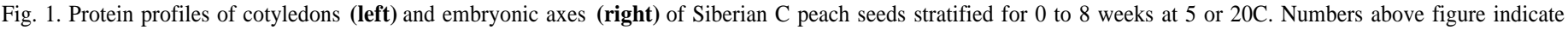

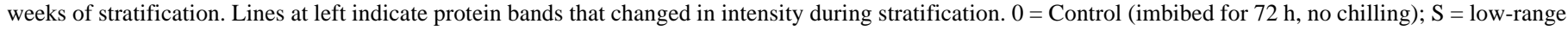

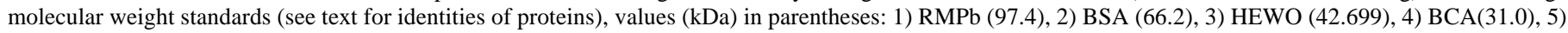
STI (21.5), 6) HEWL (14.4).

increased with time at 5C. 'Farouki' and 'Maloussi' cotyledon DWs were $\approx 78 \%$ and $88 \%$, respectively, of those of intact seeds because some portions were removed when the seeds were cut. DWs and total soluble protein content were again not affected by time at 5C (data not shown). Protein profiles in the cotyledons were unaffected by removing the embryonic axis before stratification; the two bands at 41 and $36 \mathrm{kDa}$ decreased in intensity at the same rates, and new highly mobile bands appeared as the larger polypeptides disappeared (Fig. 4). Protein profiles of axes showed no visible changes except the decrease in band intensity at 41 and 36 $\mathrm{kDa}$ observed earlier at 5 and 20C (data not shown).

Gibberellic acid. After treatment with $\mathrm{GA}_{3}, 35 \%$ to $40 \%$ of the seeds germinated without chilling, whereas, none of the control seeds germinated. Chilling further stimulated germination, which reached $90 \%$ to $95 \%$ after 4 weeks, whereas 8 weeks of chilling was required to attain similar germination percentages in the absence of $\mathrm{GA}_{3}$.

$\mathrm{GA}_{3}$ did "not affect total soluble protein content (data not shown). It hastened the loss of protein band intensity in 'Farouki' (Fig. 5) but not in 'Maloussi' cotyledons. However, GA-treated seeds germinated before any major changes occurred in proteins. The two prominent bands at 41 and $36 \mathrm{kDa}$ remained essentially unchanged in both cultivars after 1 week of chilling (Fig. 5), yet germination capacity was $50 \%$ at this time. No consistent changes in protein profile were evident in embryonic axes as a result of $\mathrm{GA}_{3}$.

\section{Discussion}

Our results can be summarized as follows: a) the concentrations of certain soluble proteins in the cotyledons decline at $5 \mathrm{C}$ but remain constant at 20C; b) similar changes do not occur in the embryonic axes; c) the presence of the embryonic axis is not required for these changes to occur; and d) these changes are not
Table 1. Effects of imbibition degree and stratification duration at $5 \mathrm{C}$ on germination (\%) at $20 \mathrm{C}$ of peach seeds of two Moroccan biotypes ('Farouki' and 'Maloussi').

\begin{tabular}{lccc}
\hline \hline Time (wks) & \multicolumn{3}{c}{ Imbibition (\%) } \\
\cline { 2 - 4 } at 5C & 25 & 50 & 100 \\
\hline \multicolumn{2}{c}{ Farouki } \\
0 & $0 \mathrm{~g}^{\mathrm{y}}$ & $0 \mathrm{~g}$ & $0 \mathrm{~g}$ \\
2 & $20 \mathrm{f}$ & $20 \mathrm{f}$ & $15 \mathrm{f}$ \\
4 & $40 \mathrm{~d}$ & $50 \mathrm{~d}$ & $30 \mathrm{e}$ \\
6 & $75 \mathrm{~b}$ & $77 \mathrm{~b}$ & $60 \mathrm{c}$ \\
8 & $90 \mathrm{a}$ & $93 \mathrm{a}$ & $90 \mathrm{a}$ \\
& $0 \mathrm{i}$ Maloussi & & \\
0 & $20 \mathrm{~g}$ & $30 \mathrm{i}$ & $0 \mathrm{i}$ \\
2 & $30 \mathrm{f}$ & $40 \mathrm{e}$ & $14 \mathrm{~h}$ \\
4 & $40 \mathrm{e}$ & $50 \mathrm{~d}$ & $67 \mathrm{c}$ \\
6 & $70 \mathrm{c}$ & $87 \mathrm{~b}$ & $97 \mathrm{a}$ \\
8 & &
\end{tabular}

$\overline{{ }^{2}}$ Fully imbibed seeds held continuously at 20C failed to germinate and partially imbibed seeds held at 5C germinated only after additional imbibition.

${ }^{y}$ Mean separation within biotypes by analysis of variance of arcsintransformed data and Duncan's multiple range test at $P \leq 0.05$.

related to germination, because germination can be prevented by axis removal or partial imbibition or hastened by $\mathrm{GA}_{3}$ without markedly affecting the protein degradation pattern.

Presumably the critical metabolic changes involved in breaking dormancy occur in the embryonic axis or are controlled by the axis. The axis could send a chemical messenger to other parts of the seed to induce hydrolytic enzyme synthesis, as is the case in barley (Hordeum vulgare L.) (Varner et al., 1964). Such a system does not seem to be involved in the protein changes observed in peach cotyledons because the process occurs without the axis. 
$5 \mathbf{C}$

$20 \mathrm{C}$

012345678

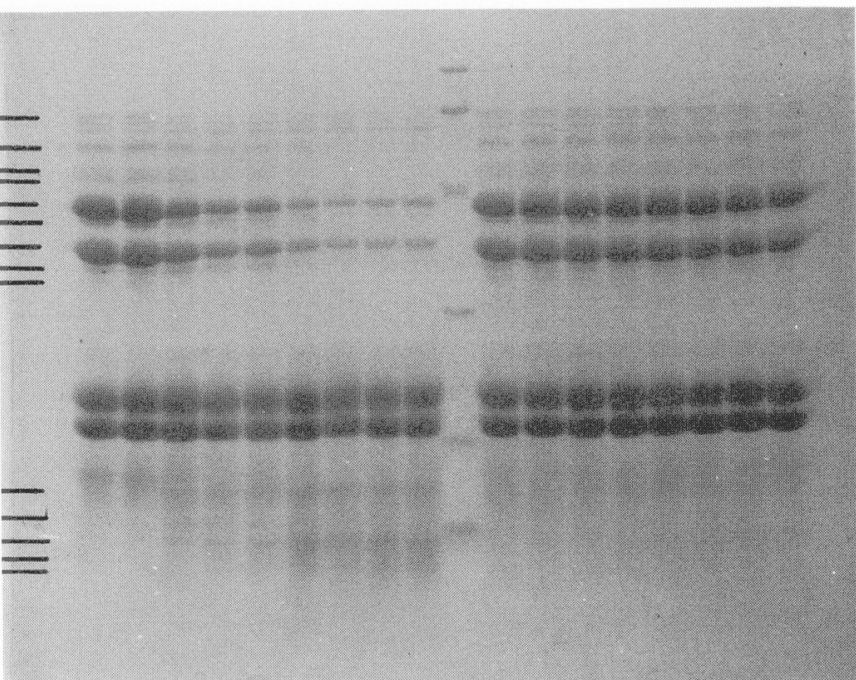

$5 \mathbf{C}$

$20 \mathrm{C}$ $\overline{012345678}$ s $\longdiv { 1 2 3 4 5 6 7 8 }$

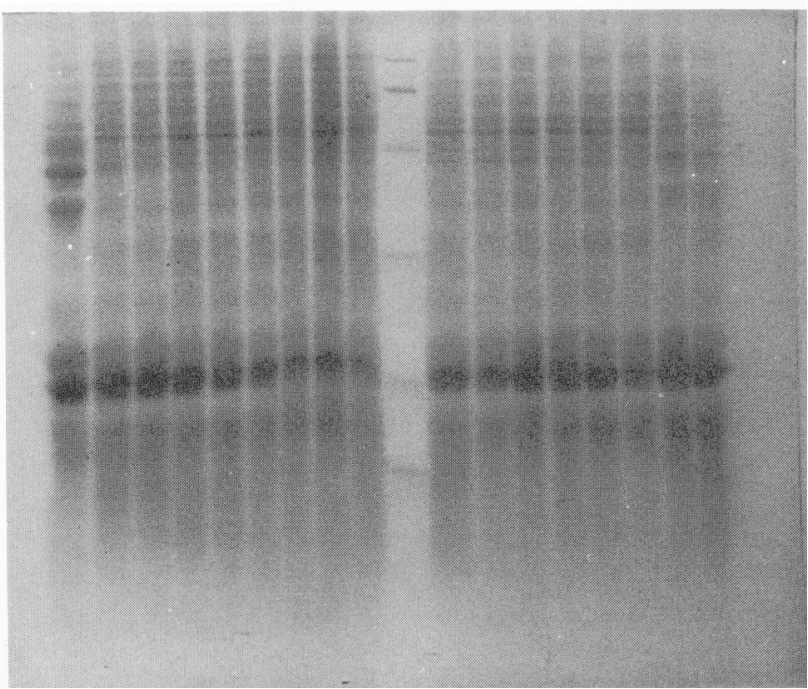

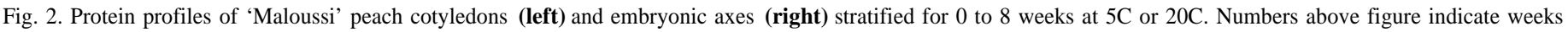

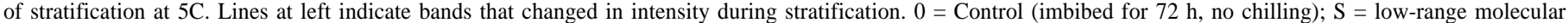

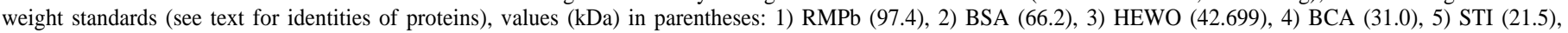
6) HEWL (14.4).

IMBIBITION (HR)

72
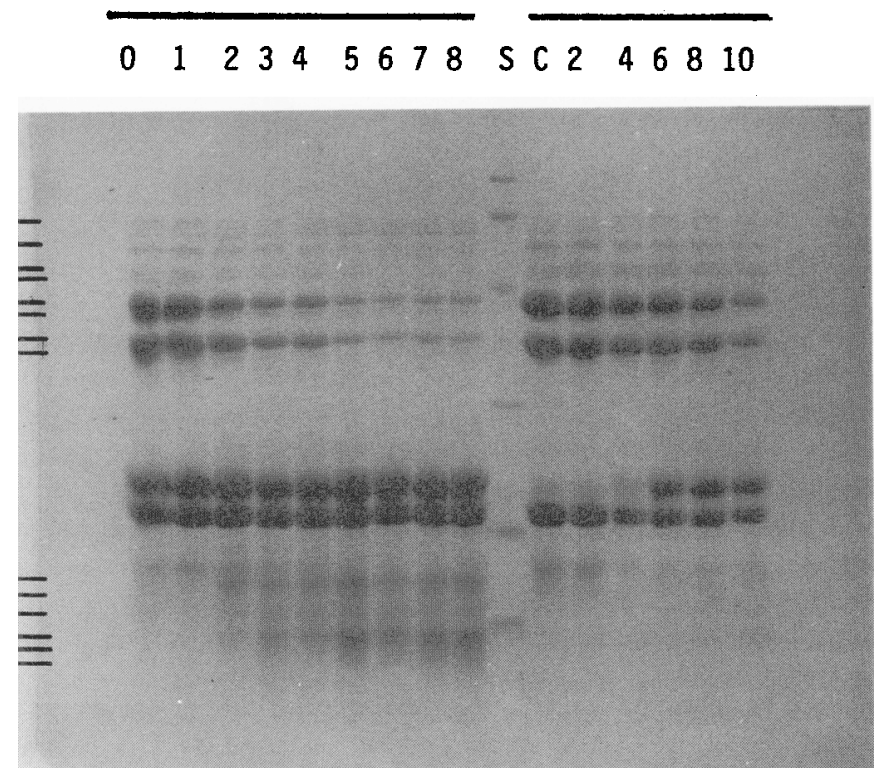

72

15
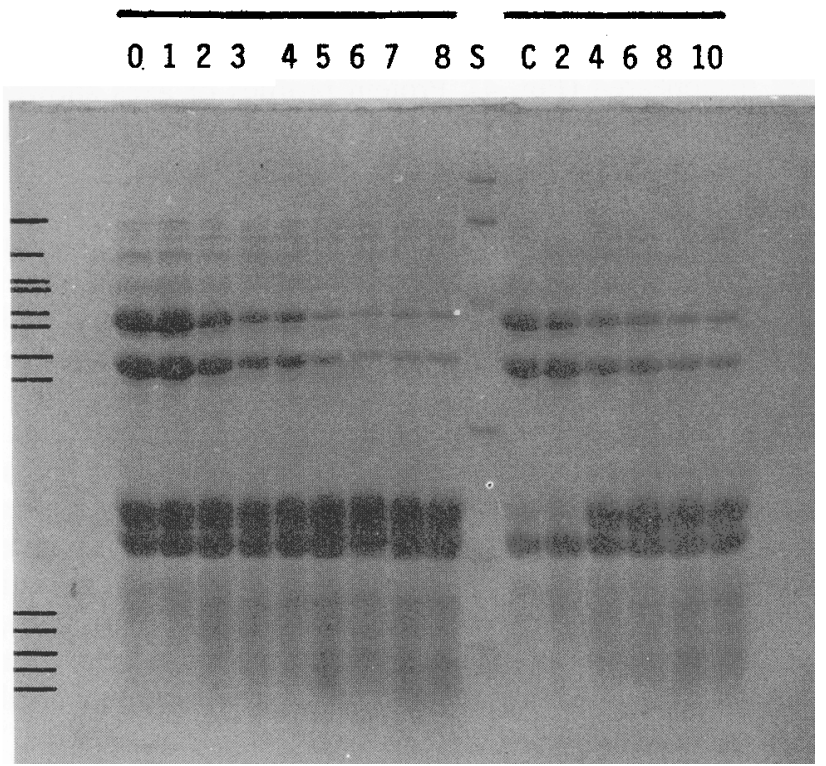

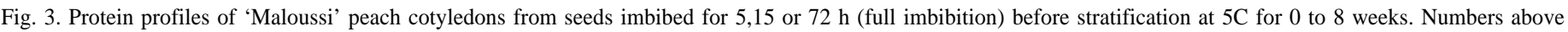

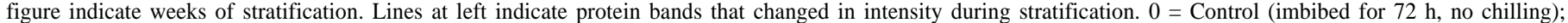

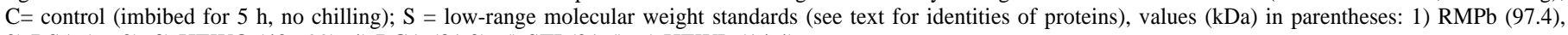
2) BSA (66.2), 3) HEWO (42.699), 4) BCA (31.0), 5) STI (21.5), 6) HEWL (14.4). 
012345678512345678

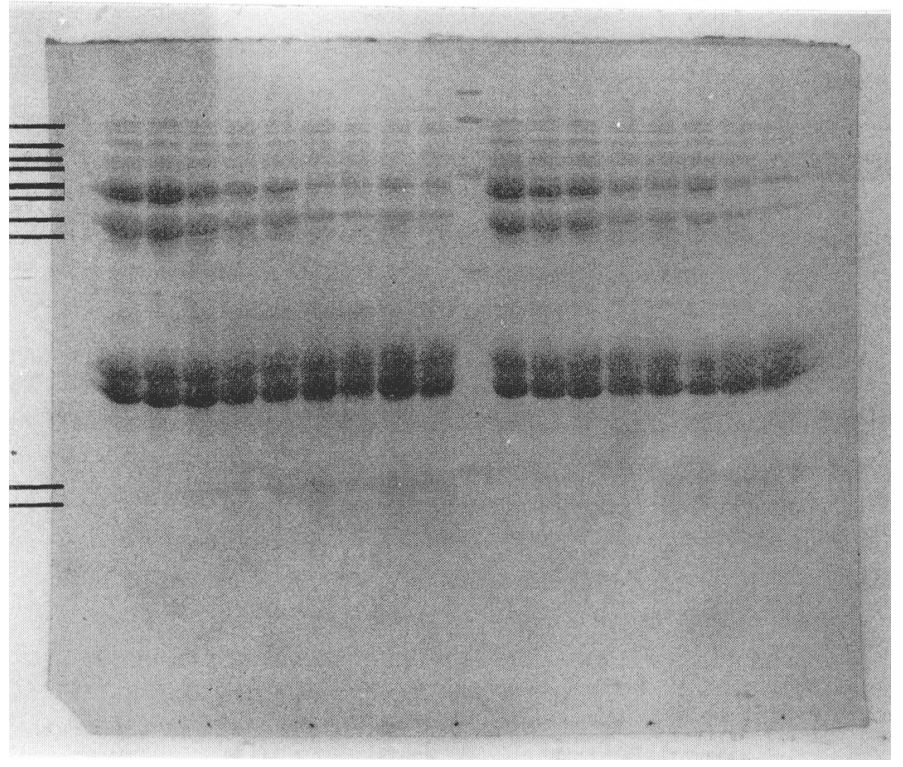

Fig. 4. Protein profiles of 'Maloussi' peach cotyledons stratified for 0 to 8 weeks in the presence (left) or the absence (right) of embryonic axes. Numbers above figure indicate weeks of stratification at $5 \mathrm{C}$. Lines at left indicate protein bands that changed in intensity during stratification. $0=$ Control (imbibed for $72 \mathrm{~h}$, no chilling); $\mathrm{S}=$ low-range molecular weight standards (see text for identities of proteins), values ( $\mathrm{kDa}$ ) in parentheses: 1) RMPb (97.4), 2) BSA (66.2), 3) HEWO (42.699), 4) BCA (31.0), 5) STI (21.5), 6) HEWL (14.4).

NO GA

$0 1 2 3 4 5 6 7 8 5 \longdiv { 0 1 2 3 4 }$

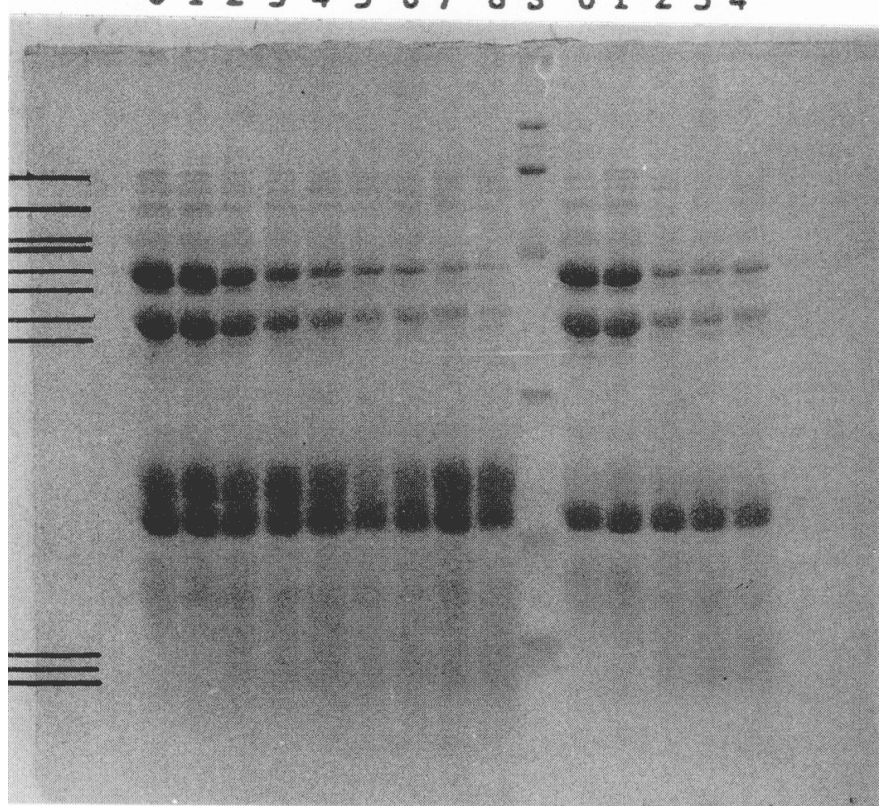

Fig. 5. Effects of gibberellic acid ( $\mathrm{GA}_{3}$ at $500 \mathrm{ppm}$ for $24 \mathrm{~h}$ before stratification) on protein profiles of 'Faronki' peach cotyledons from seeds stratified for 0 to 8 weeks. Numbers above figure indicate weeks of stratification at $5 \mathrm{C}$. Lines at left indicate protein bands that changed during stratification. No $\mathrm{GA}_{3}, 0=$ control (imbibed for $72 \mathrm{~h}$, no chilling); $\mathrm{GA}_{3}, 0=$ control (imbibed for $48 \mathrm{~h}$, then soaked in $\mathrm{GA}_{3}$ solution for $24 \mathrm{~h}$, no chilling); $\mathrm{S}=$ low-range molecular weight standards (see text for identities of proteins), values (kDa) in parentheses: 1) RMPb (97.4), 2) BSA (66.2), 3) HEWO (42.699),4) BCA (31.0), 5) STI (21.5), 6) HEWL (14.4).
Processes involved in breaking dormancy are often difficult to separate from those occurring during germination. The changes observed in this study were clearly separated from germination in that a) the embryonic axis was not essential; b) the changes occurred, although at a slower rate, in partially imbibed seeds that could not germinate; and c) germination induced by $\mathrm{GA}_{3}$ did not induce protein changes in the cotyledons. These facts indicate that the protein changes were the result of chilling, per se, rather than of processes associated with germination.

One-dimensional SDS-PAGE was used in this work; this method separated some 30 or 40 individual proteins. However, plants contain thousands of proteins; therefore, proteins specific to either dormant or nondormant seeds could easily have been overlooked. Incubating seeds with ${ }^{35} \mathrm{~S}$-labeled amino acids to label newly synthesized proteins is a much more powerful technique for detecting protein differences in response to chilling. Recent experiments with sugar maple (Acer saccharum Marsh.) (Hance and Bevington, 1991) and pear (Pyrus serotina Rehd.) (Lin et al., 1991) seeds indicate that dormancy release by chilling is associated with alterations in polypeptide constituents. In sugar maple, two proteins present in cotyledons of nonchilled seeds were absent from those of chilled seeds. In pear seeds, changes occurred during chilling in both cotyledons and axis proteins, some increasing, some decreasing, and others appearing de novo. Further research using cloned genes of specific proteins could provide new insight into the differences between dormant and nondormant tissues.

\section{Literature Cited}

Alscher-Herman, R., A.A. Khan. 1980. Polyribosomes and protein synthesis in after-ripening pear seeds. Physiol. Plant. 48:285-291.

Bouvier-Durand, M., A. Dawidowicz-Grzegorzewska, C. Thévenot, and D. Côme. 1983. Dormancy of apple embryos. Are starch and reserve protein changes related to dormancy breaking? Can. J. Bot. 62:2308-2315.

Bradford, M.M. 1976. A rapid and sensitive method for the quantitation of microgram quantities of protein utilizing the principle of protein-dye binding. Anal. Biochem. 72:248-254.

Callaway, A.S. 1988. Analysis of translational products correlated with rest release of Prunus persica. MS thesis. Univ. of Georgia, Athens.

Donoho, C.W. and D.R. Walker. 1957. Gibberellic acid and the chilling requirement of peach seeds. Science 126: 1178-1 179.

Eichholtz, D.A., H.A. Robitaille, and K.M. Herrmann. 1983. Protein changes during the stratification of Malus domestica Borkh. seed. Plant Physiol. 72:750-753.

Hance, B.A. and J.M. Bevington. 1991. Changes in protein synthesis in sugar maple embryos during stratification and dormancy release. Plant Physiol 96:63. (Suppl.)

Laemmli, U.K. 1970. Cleavage of structural proteins during the assembly of the head of bacteriophage T4. Nature 227:680-685.

Lang, G.A. and J. Tao. 1991. Dormant peach flower bud proteins associated with chill unit accumulation or negation temperatures. HortScience 26:733. (Abstr.)

Lin, C.H., L.Y. Lee, and M.-J. Tseng. 1991. Effects of stratification and thidiazuron treatment on germination and protein synthesis of Pyrus serotina Rehd. cv. Niauli. Plant Physiol. 96:404. (Suppl.)

Noland, T.L. and J.B. Murphy. 1986. Protein synthesis and aminopeptidase activity in dormant sugar pine seeds during stratification and warm incubation. J. Plant Physiol. 124:1-10.

Stokes, P. 1952. A physiological study of embryo development in Heracleum sphondylium. I. Effect of temperature on embryo development. Ann. Bot. 16:441-447.

Vainer, J.E. 1964. Gibberellic acid-controlled synthesis of $\alpha$-amylase in barley endosperm. Plant Physiol. 39:413-415. 